\title{
Synthesis, Characterization and Catalytic Evaluation of Cobalt and Niobium Oxide Solids Modified with Alkaline Earth Metals
}

\author{
Maiana Pinheiro Sena ${ }^{1}$, Simone Pereira de Lima ${ }^{2}$, \\ Luciene Santos Carvalho ${ }^{3}$, Doris Ruiz ${ }^{4}$, Adriana Ballarini ${ }^{5}$, André Rosa Martins ${ }^{1}$
}

\begin{abstract}
${ }^{1}$ Instituto Federal da Bahia, Campus Porto Seguro, BR 367, Km 57,5, Fontana I,CEP: 45810-000, Porto Seguro, BA, Brazil ${ }^{2}$ Instituto Federal da Bahia, Campus Salvador, Rua Emídio dos Santos, s/n, Barbalho,CEP: 40301-015, Salvador, BA, Brazil ${ }^{3}$ Instituto Federal da Bahia, Campus Camaçari, Av. Jorge Amado, s/n, Jd. Limoeiro, CEP: 42800-605, Camaçari, BA, Brazil ${ }^{4}$ Universidad de Concepción, Facultad de Ciencias Químicas, Edmundo Larenas, 129, Concepcion, Biobío, Chile.

${ }^{5}$ Instituto de Investigaciones en Catálisis y Petroquímica, CONICET-Universidad Nacional del Litoral, 3000, Santa Fé, Vera Cruz, Argentina.

e-mail: pinheiro.maiana@gmail.com, simonepereiradelima@gmail.com, lusantos@ifba.edu.br,doruiz@udec.cl, adriballa@hotmail.com, andremartins@ifba.edu.br
\end{abstract}

\begin{abstract}
Cobalt and niobium oxide solids modified with alkaline earth metals $(\mathrm{Mg}, \mathrm{Ca}$, and $\mathrm{Sr}$ ) were synthesized and characterized to compare the second element effect on the catalyst structural and chemical properties. The materials were prepared by co-precipitation of cobalt nitrate and niobium oxalate solutions using ammonium hydroxide as precipitating agent. The samples were characterized by XRD, SEM, Ra-man, BET, TPR, ammonia TPD and cyclohexane dehydrogenation reaction (CHD). Results showed that $\mathrm{Mg}, \mathrm{Ca}$ or $\mathrm{Sr}$ addition changed cobalt niobate crystalline structure, leading to alkaline earth metal nio-bates with lower crystallinity. It was observed that $\mathrm{Mg}$, $\mathrm{Ca}$ or $\mathrm{Sr}$ increased the solids acidity and changed cobalt niobate reduction behavior so that the lowest amount of metallic cobalt was obtained when $\mathrm{Mg}$ was incorporated. Modifiers also decreased cobalt niobate dehydrogenation activity. This effect was higher with $\mathrm{Mg}$ or $\mathrm{Sr}$ addition.
\end{abstract}

Keywords: cobalt niobate, alkaline earth metals; XRD; TPR; cyclohexane dehydrogenation.

\section{INTRODUCTION}

The use of catalysts is an efficient way to produce chemicals to meet the growing demand for chemical industry. In this context, the use of catalyst for hydrogen production is highlighted as a function of the hydrogen potential as fuel cells energy source. In order to do that, the primary industrial process used is hydrocarbon reforming [1]. The active catalysts used in this process need to have dehydrogenating property, that is, the ability of breaking the hydrogen bond in compounds. The most used catalyst in industry for hydrocarbon reforming is nickel/alumina, which is active and selective at low costs.

Cobalt is another transition metal used as catalyst active phase in industrial reactions. It presents activity to decomposition, dehydrogenation, hydrogenation, hydrogenolysis and hydrodesulfurization reactions. It is also used in catalysts for cyclohexane oxidation [2], methane decomposition [3, 4], Fischer Tropsch synthesis [5, 6], methane or ethanol reforming for hydrogen production [3, 4, 7, 8,9], including fuel cell studies [10], although it shows lower selectivity to hydrogen compared to nickel catalyst [11], pollutant degradation [12] and others. Cobalt catalyst activity and selectivity depends considerably on the support type and preparation method [7, 13, 14, 15]. For example, cobalt based supported catalysts were evaluated in dry methane reforming and showed high dependence on the support nature $\left(\mathrm{MgO}, \mathrm{CaO}\right.$, or $\left.\mathrm{SiO}_{2}\right)[16]$. Nowadays, many studies are based on cobalt supported over different oxides, besides traditional alumina [7, 8, 14] .

Niobium is another metal that has received a lot of prominence in recent years. It has peculiar physical and chemical characteristics that make different systems useful, such as solid electrolytic capacitors, photochromic devices, transparent conductive oxides or memristors, catalysists [17]. Niobium oxide became a widely studied catalyst support, which presents essential catalytic properties such as stability, among others [18]. Besides, it can act as a catalyst in various reactions such as hydrogenation, dehydrogenation, dehydration, esterification and oxidation [5]. Brazil has the largest niobium reserve in the world (above 90\%), therefore it is an extra motivation for the development of new technologies that use niobium derivates $[16,19]$. Regarding the use of niobium oxide in methane, ethanol or other carbon compounds reforming, niobium 
oxide may have a disadvantage related to its high surface acidity, which could favor coke formation, carbon-rich species deposition on the catalyst surface and active sites blockage [20,21]. On the other hand, although much studied, there is still contradictory information regarding niobium oxide properties. This occurs especially when studying its phases, due to the tendency to present crystal polymorphs and different phases, consequently running different catalysts [17].

The addition of modifiers to the support could be a solution for such a problem. Due to their basic character, modifiers such as alkali and alkaline earth metal oxides may decrease the support acidity and consequently the amount of carbonaceous deposits on its surface $[20,22]$. For $\mathrm{Ni} / \mathrm{Al}_{2} \mathrm{O}_{3}$ catalysts, a decrease in acidity due to alkaline earth metal oxides addition was directly related to coke deposition decrease on the surface [23]. However, other catalytic properties may change with alkaline metal addition, such as metallic dispersion, active phase species reduction degree on the surface and its interaction with the support, which also affects their activity and selectivity [1, 10, 24]. Studies show that the catalyst behavior can be significantly altered depending on the nature of the alkaline earth metal used as a dopant [25]. In addition, alkaline earth niobate metals formed from the materials mentioned above may be used in other fields, due to their dielectric properties [17, 26]. $\mathrm{MgNb}_{2} \mathrm{O}_{6}$, for example, is widely used as a precursor to synthesize other columbites while $\mathrm{CoNb}_{2} \mathrm{O}_{6}$ has interesting magnetic properties and $\mathrm{CaNb}_{2} \mathrm{O}_{6}$ has useful optical properties [27, 28]. Other authors claim that $\mathrm{ANb}_{2} \mathrm{O}_{6}(\mathrm{~A}=$ $\mathrm{Ba}^{2+}, \mathrm{Sr}^{2+}, \mathrm{Mg}^{2+}, \mathrm{Sn}^{2+}, \mathrm{Zn}^{2+}$, among others) columbite structure exhibits excellent performance in tests of magnetic, dielectric, thermoelectric and piezoelectric properties [29].

Thus, in this work, solids based on cobalt and niobium oxide modified with alkaline earth metals $(\mathrm{Mg}, \mathrm{Ca}, \mathrm{Sr})$ were synthesized and characterized to evaluate some properties and catalytic behavior, mainly due to dopants.

\section{MATERIALS AND METHODS}

\subsection{Samples Preparation}

Solids were prepared by co-precipitation method, using cobalt nitrate and niobium oxalate solutions as metallic precursors, and ammonium hydroxide as precipitating agent. Solutions were mixed slowly under constant stirring at $\mathrm{pH}=9.0$. After precipitation, the reaction mixture was heated to $90{ }^{\circ} \mathrm{C}$ under continuous stirring until solvent excess evaporation. The material was dried at $120^{\circ} \mathrm{C}$ for $24 \mathrm{~h}$ and calcined at $800^{\circ} \mathrm{C}$ for $2 \mathrm{~h}$, producing the CoNb sample (the solid was synthesized to obtain $\mathrm{Co}: \mathrm{Nb}$ at 2:7 atomic ratio). The same procedure/methodology was followed to prepare $\mathrm{CoMgNb}, \mathrm{CoCaNb}$, and $\mathrm{CoSrNb}$ samples using magnesium nitrate, calcium nitrate and strontium nitrate as metallic precursors, respectively. The solids were synthesized to obtain $\mathrm{Co}: \mathrm{M}: \mathrm{Nb}$ at 2:1:7 atomic ratio, in which $\mathrm{M}=\mathrm{Mg}, \mathrm{Ca}, \mathrm{Sr}$.

\subsection{Samples Characterization}

Samples were characterized by X-ray diffraction (XRD), scanning electron microscopy (SEM), specific area measurements (BET method), Raman spectroscopy, temperature programmed reduction (TPR), ammonia temperature programmed desorption $\left(\mathrm{NH}_{3}-\mathrm{TPD}\right)$ and cyclohexane dehydrogenation reaction (CHD).

X-ray diffraction (XRD) analyses were performed using Shimadzu XRD600 equipment with nickel filter. The sample was submitted to $\mathrm{CuK} \alpha$ radiation, which was generated at $30 \mathrm{kV}$ and $20 \mathrm{~mA}$, and the scan ranged from $10^{\circ}$ to $80^{\circ}$. The phases were identified using the Inorganic Crystal Structure Database (ICSD).

Scanning Electron Microscopy (SEM) images were obtained through Tescan Vega-3 LMU equipment at $15 \mathrm{kV}$ and 7000x magnification. Energy Dispersive X-ray Spectroscopy (EDS) analyses were performed in an X-act Oxford Instruments apparatus coupled to the electron microscope.

Samples specific area values were determined by physical nitrogen adsorption isotherms at $-196{ }^{\circ} \mathrm{C}$ in a Micromeritics TriStar II 3020 equipment. Before the experiment, the samples were pre-treated at $10 \mu \mathrm{mHg}$ for $30 \mathrm{~min}$ and then heated at $200{ }^{\circ} \mathrm{C}$ for $60 \mathrm{~min}$ under nitrogen flow for surface cleaning. After pretreatment, the dead volume and the saturation pressure, $\mathrm{P}^{\circ}$, were determined using $99.999 \%$ pure helium gas. Before analyses, samples were heated at $200{ }^{\circ} \mathrm{C}(2 \mathrm{~h})$ under $10^{-6}$ Torr vacuum.

Raman spectra were obtained to determine the species crystalline structure in the solids. Analyses were performed at room temperature throug a Jasco NRS-5100 spectrometer, equipped with a TCD cooled at $-69^{\circ} \mathrm{C}$, under the following conditions: $532.13 \mathrm{~nm}$ wavelength, 20x objective, 100-2000 nm spectral scanning, $6.0 \mathrm{~mW}$ laser power and $14 \mathrm{~cm}^{-1}$ spectrum resolution. The sample was exposed to laser ten times to reduce background noise, 10s each time (accumulations number and exposure time, respectively). The analysis was performed repeatedly to observe different parts of the solids.

Temperature programmed reduction (TPR) analyses were performed in a Micromeritics AutoChem 2920 equipment. 
Before the experiments, 0.050 to $0.150 \mathrm{~g}$ samples were pretreated by heating at $160{ }^{\circ} \mathrm{C}$ for $30 \mathrm{~min}$ under nitrogen atmosphere in order to remove volatile compounds. During analyses, samples were heated from 30 to $1000{ }^{\circ} \mathrm{C}$ at $10{ }^{\circ} \mathrm{C} \cdot \mathrm{min}^{-1} \mathrm{under}^{-}$ $5 \% \mathrm{H}_{2} / \mathrm{N}_{2}$ flow $\left(30 \mathrm{~mL} \cdot \mathrm{min}^{-1}\right)$.

Samples whole acidity was determined by ammonia temperature programmed desorption ( $\left.\mathrm{NH}_{3}-\mathrm{TPD}\right)$. The analyses were performed in a Micromeritics TPD/TPR 2900 equipment, using $0.05 \mathrm{~g}$ sample, which was initially heated at $150{ }^{\circ} \mathrm{C}$ for $1 \mathrm{~h}$ under He flow to remove impurities. After pretreatment step, the sample was cooled to room temperature and heated again under $\mathrm{H}_{2}$ flow $\left(35 \mathrm{~mL} \cdot \mathrm{min}^{-1}\right)$ at $500{ }^{\circ} \mathrm{C}$ for $1 \mathrm{~h}$. Ammonia adsorption was carried out by this gas pulses injection through a calibrate loop kept at $75^{\circ} \mathrm{C}$, until sample saturation. The system was cooled to room temperature and then heated to $775^{\circ} \mathrm{C}$, under He flow, to obtain the ammonia temperature programmed desorption profiles. The acidity was calculated from ammonia adsorption peaks areas, taking the last peak for calibration.

Metallic activity was evaluated by cyclohexane dehydrogenation reaction (CHD). The tests were carried out in a continuous flow micro-reactor, at atmospheric pressure, $400{ }^{\circ} \mathrm{C}$ and $\mathrm{H}_{2}$ /cyclohexane (molar) $=26$. Before each run, the samples $(0.05 \mathrm{~g})$ were reduced in situ at $500{ }^{\circ} \mathrm{C}$ for $2 \mathrm{~h}$, under hydrogen flow. Cyclohexane and reaction products were analyzed by gas chromatography using a Chromosorb column and TCD as detector.

\section{RESULTS AND DISCUSSION}

XRD profiles indicated that the samples had several phases (Fig. 1). This is in accordance with the literature for niobium-based solids, obtained by traditional methods of synthesis [17, 26, 27]. The non-doping sample (CoNb) showed orthorhombic cobalt niobate, $\mathrm{CoNb}_{2} \mathrm{O}_{6}$ (ICSD 01-072-0482 / JCPDS 32-0304), as the main phase and discrete evidence from $\mathrm{Co}_{4} \mathrm{Nb}_{2} \mathrm{O}_{9}$ phase (ICSD 00-038-1457 / [30]). This is a less common phase, with trigonal structure, which is generally studied focusing the crystal magnetic properties [27]. In addition, peaks were also detected regarding cobalt oxide, $\mathrm{Co}_{3} \mathrm{O}_{4}$ (ICSD 01-0761802 / JCPDS 74-2120), and niobium oxide, $\mathrm{Nb}_{2} \mathrm{O}_{5}$ phase (ICSD 00-027-1313 / JCPDS 71-1176). In the other samples, in addition to cobalt oxide, alkaline earth metal niobate was formed in each sample, $\mathrm{MgNb}_{2} \mathrm{O}_{6}$ (ICSD 00-033-0875 / JCPDS 2505-26), $\mathrm{CaNb}_{2} \mathrm{O}_{6}$ (ICSD 00-039-1392 / [31]) and $\mathrm{SrNb}_{2} \mathrm{O}_{6}$ (ICSD 00-045-0227). CoMgNb sample diffraction pattern was similar to that of CoNb sample. Magnesium niobate phase diffraction peaks, $\mathrm{MgNb}_{2} \mathrm{O}_{6}$ (ICSD 00-033-0875 / JCPDS 2505-26), coincide with those of cobalt niobate phase, as also reported by other authors [8].

Magnesium ions incorporation into cobalt niobate crystalline structure is facilitated because $\mathrm{Mg}^{2+}$ has low ionic radius value $(0.72 \AA)$. On the other hand, this did not happen with $\mathrm{Ca}^{2+}$ and $\mathrm{Sr}^{2+}$ ions, because they have higher ion radius values, 1.00 and $1.18 \AA$, respectively [32]. Regarding the variety of phases found, other authors also observed cobalt niobate different phases formation $[8,13,31,33]$ because, just like niobium, cobalt can assume different oxidation states and shows varied phases, depending on the support and the preparation method $[7,8,15,29] \cdot \mathrm{Nb}_{2} \mathrm{O}_{5}$ phase is considered to be very stable and, therefore, desirable for catalytic systems operating at high temperatures [34]. However, this phase was not detected in $\mathrm{CoCaNb}$ or CoSrNb DRX samples profiles, which may indicate that there was no phase segregation and / or small and dispersed particles formation. Comparing DRX profiles, it can be seen that lower intensity peaks were obtained when alkaline earth metals were incorporated into cobalt niobate. It indicates that dopant addition impaired the solids crystallinity, because the niobate structure has been distorted due to the cation radius [34]. Among the formed niobate phases, $\mathrm{MgNb}_{2} \mathrm{O}_{6}$ is the most studied [26, 27, 30]. It can be difficult to be formed in the single phase, and it may be accompanied by $\mathrm{Mg}_{4} \mathrm{Nb}_{2} \mathrm{O}_{9}$ phase $[27,31]$, which was not observed in this work. 


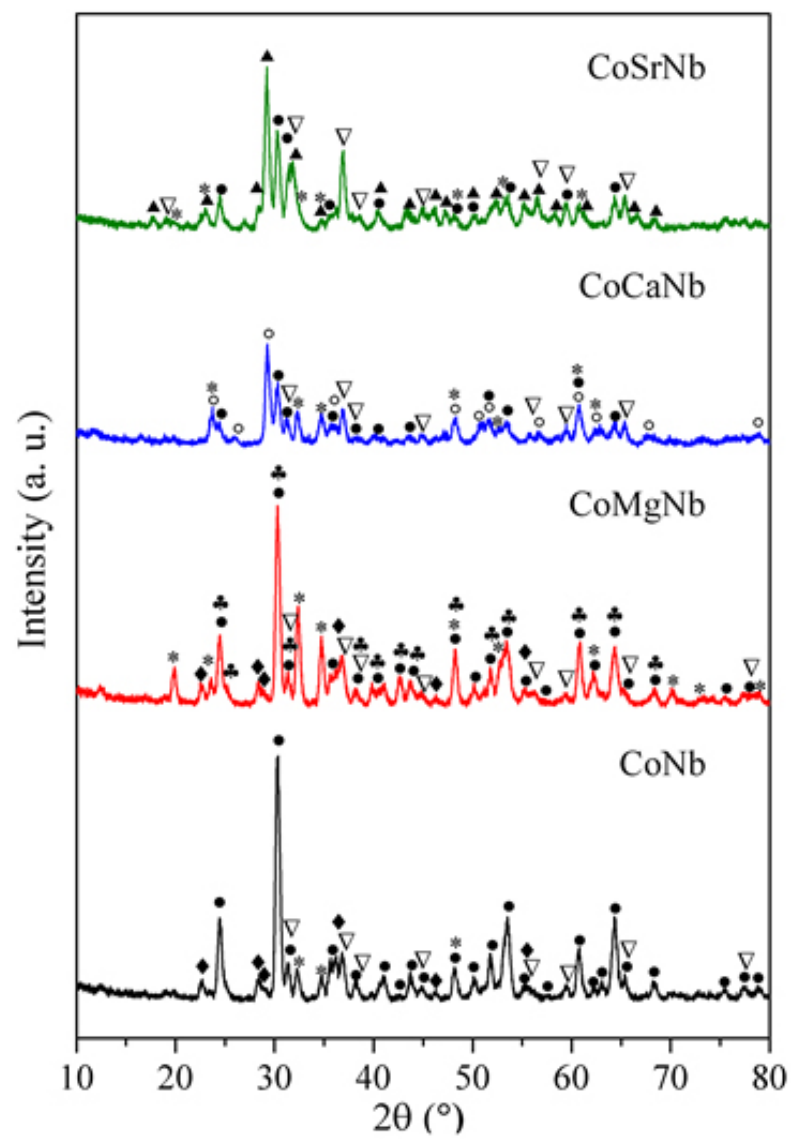

Figure 1: Cobalt niobate based samples X-ray diffractograms with phases identification: $\mathrm{CoNb}_{2} \mathrm{O}_{6}(\bullet) ; \mathrm{Co}_{3} \mathrm{O}_{4}(\nabla) ; \mathrm{Nb}_{2} \mathrm{O}_{5}$ $(\bullet) ; \mathrm{Co}_{4} \mathrm{Nb}_{2} \mathrm{O}_{9}(*) ; \mathrm{MgNb}_{2} \mathrm{O}_{6}(*) ; \mathrm{CaNb}_{2} \mathrm{O}_{6}(\mathrm{O}) ; \mathrm{SrNb}_{2} \mathrm{O}_{6}(\boldsymbol{\Delta})$.

SEM images (Fig. 2) suggest the all solids had particles of irregular shapes, highly agglomerated and with different sizes on the surface. This behavior is common for niobates obtained by traditional synthesis routes, as noted by other authors $[26,30]$. It was also possible to observe the presence of lighter color smaller particles agglomerates over darker color larger particles. It is in accordance with XRD results, which indicate different metal oxides formation in each of the studied solids. Probably, the darker color particles are cobalt niobates, which are present in a higher amount. Materials surface atomic distribution, evaluated from elemental analysis by EDS, showed that $\mathrm{Co} / \mathrm{Nb}$ and $\mathrm{Co} / \mathrm{M}$ atomic ratios found for $\mathrm{CoNb}$ and $\mathrm{CoMgNb}$ samples, respectively, were close to nominal values. However, these atomic ratio values were higher for $\mathrm{CoCaNb}$ and lower for $\mathrm{CoSrNb}$, as observed from Table 1. This can indicate that there is a higher concentration of cobalt oxides on $\mathrm{CoCaNb}$ sample surface compared to the others.

Raman spectra can be seen in Fig. 3. Scan was performed in order to collect data from different points on the sample surface. It can be observed that for the sample without dopant and the sample with magnesium, two different spectra profiles were obtained, while only one was obtained with the other samples (CoCaNb and CoSrNb). In all samples, the absorption bands found at $870,530,702,283$, and $253 \mathrm{~cm}^{-1}$ can be attributed to both niobium and cobalt species [28, 33]. The different lines found are in agreement with XRD results which indicated that the cobalt and niobium species can be distributed in different structures: $\mathrm{CoNb}_{2} \mathrm{O}_{6}$ (orthorhombic), $\mathrm{Co}_{3} \mathrm{O}_{4}$ (spinel), $\mathrm{Co}_{4} \mathrm{Nb}_{2} \mathrm{O}_{9}$ (trigonal) [28]. The highest peak at $870 \mathrm{~cm}^{-1}$ is attributed to niobium species, probably cobalt niobate, with orthorhombic structure [8]. A shift from this peak for higher frequency regions regarding $\mathrm{CoMgNb}$ sample may indicate a network distortion as a function of magnesium insert. On the other hand, the shoulder at $780 \mathrm{~cm}^{-1}$ for $\mathrm{CoNb}$ and $\mathrm{CoMgNb}$ samples spectra can be attributed to niobium oxide phase $\left(\mathrm{Nb}_{2} \mathrm{O}_{5}\right)$, as identified by XRD. 

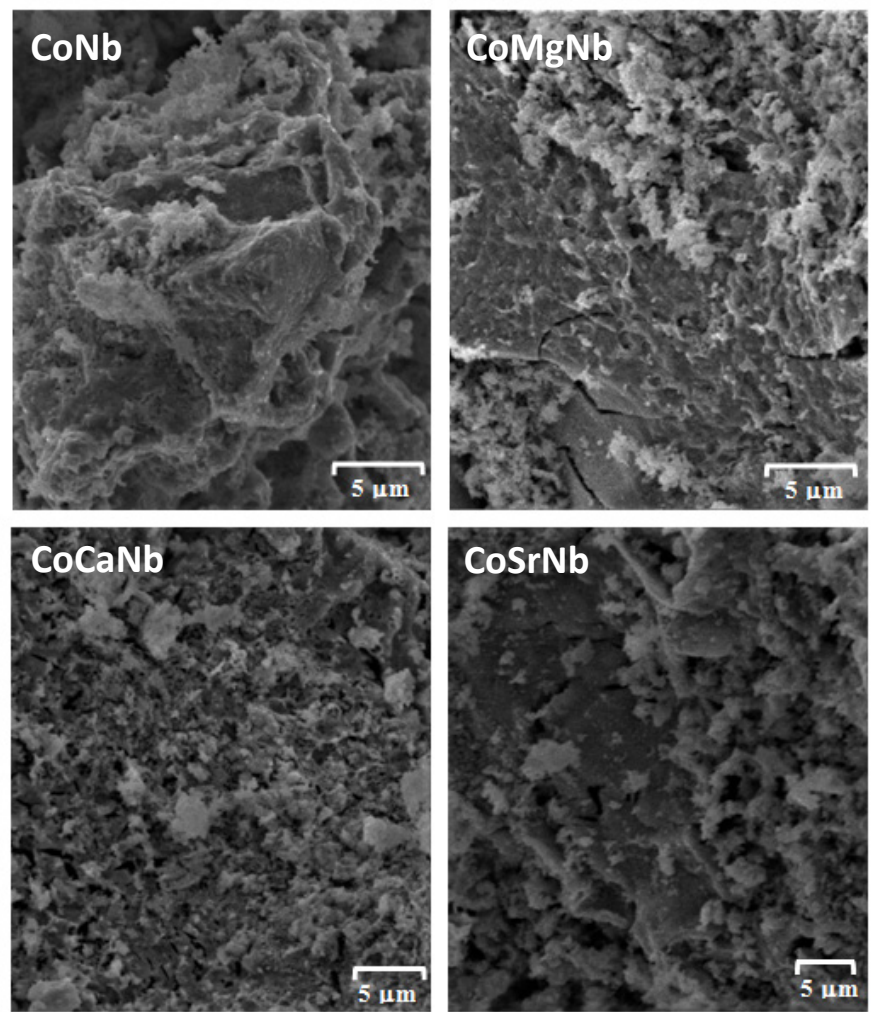

Figure 2: Cobalt niobate based samples SEM images $(7,00 \mathrm{kX})$.

Table 1: Specific area ( $\mathrm{Sg})$, mean pore diameter $(\mathrm{PD})$, samples total acidity, $\mathrm{Co} / \mathrm{Nb}, \mathrm{Co} / \mathrm{M}$ and $\mathrm{M} / \mathrm{Nb}(\mathrm{M}=\mathrm{Mg}, \mathrm{Ca}$ or $\mathrm{Sr})$ atomic ratio values obtained by EDS.

\begin{tabular}{l|c|c|c|c|c|c}
\hline \multicolumn{1}{c|}{ SAMPLE } & $\mathbf{S g}\left(\mathbf{m}^{\mathbf{2}} \mathbf{g}^{-1}\right)$ & $\mathbf{P D}(\mathbf{n m})$ & TOTAL ACIDITY $\left(\mathbf{m m o l ~}_{\mathbf{~ N H}} \mathbf{g}^{-1}\right)$ & $\mathbf{C o} / \mathbf{N b}$ & Co/M & $\mathbf{M} / \mathbf{N b}$ \\
\hline $\mathrm{CoNb}$ & 2 & 30 & 3 & 0.32 & - & - \\
\hline $\mathrm{CoMgNb}$ & 5 & 25 & 8 & 0.66 & 2.0 & 0.32 \\
\hline $\mathrm{CoCaNb}$ & 4 & 25 & 7 & 0.91 & 3.4 & 0.26 \\
\hline $\mathrm{CoSrNb}$ & 6 & 24 & 16 & 0.47 & 1.0 & 0.46 \\
\hline
\end{tabular}

The bands shown at 732 and $687 \mathrm{~cm}^{-1}$, observed almost exclusively for CoSrNb sample, can be attributed to strontium presence. Peaks from 700 to $190 \mathrm{~cm}^{-1}$ can be related to cobalt oxide, $\mathrm{Co}_{3} \mathrm{O}_{4}[8,34]$. Finally, the spectral region from 145 to $186 \mathrm{~cm}^{-1}$ can be associated to niobium oxide, $\mathrm{NbO}_{2}$ [17]. Thus, Raman spectra also corroborate XRD results, indicating strong interaction between dopant and support, possibly due to magnesium ions incorporation to cobalt niobate structure. CoSrNb sample stands out for presenting more peaks with more intensity than the other ones. This may indicate, in addition to more phases (not detected by XRD), more covalent character metal-O bonds [33], once strontium decreases the solid hygroscopic character, compared to other alkaline earth metals. 


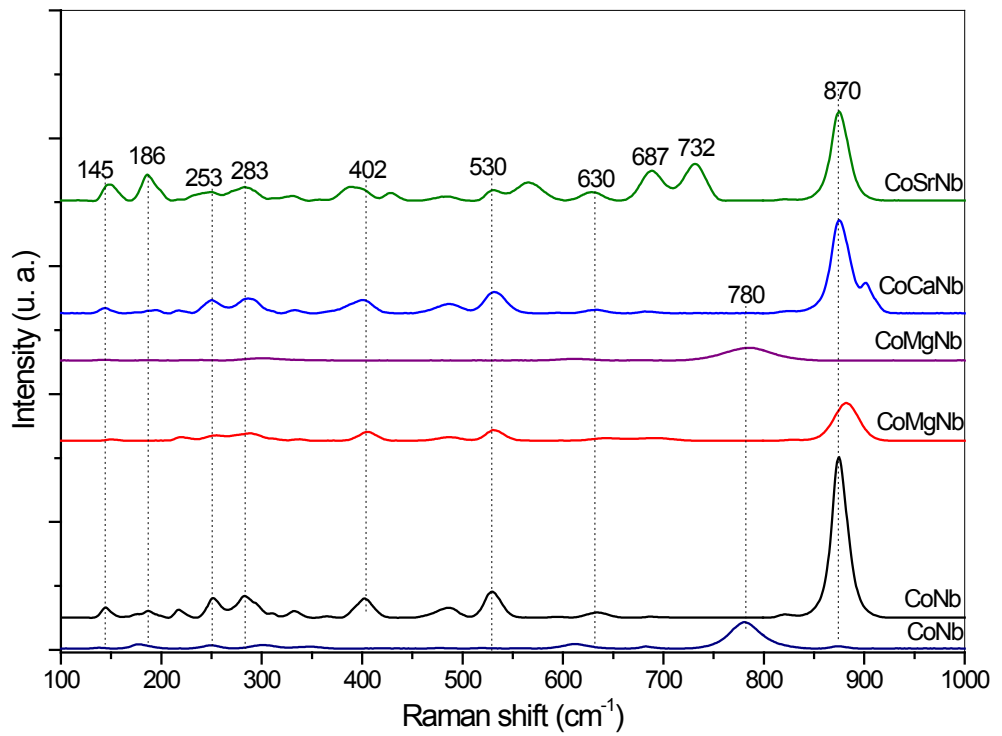

Figure 3: Cobalt niobate based samples Raman spectra.

TPR profiles indicate that cobalt niobate reduction behavior (Fig. 4) was modified with $\mathrm{Mg}, \mathrm{Ca}$ or $\mathrm{Sr}$ addition. In all cases, cobalt species reduction occurred between 250 and $450{ }^{\circ} \mathrm{C}$, in agreement with other works, while niobium species reduction occurred above $700{ }^{\circ} \mathrm{C}[31]$. Also, according to literature [16, 27, 2], $\mathrm{Co}_{3} \mathrm{O}_{4}$ reduction, which is a phase present in all DRX profiles, occurs in two stages. However, in this work this phenomenon was only observed for $\mathrm{CoNb}$ and $\mathrm{CoMgNb}$ samples, in which the shoulder at $336{ }^{\circ} \mathrm{C}$ can be attributed to $\mathrm{Co}^{3+}$ reduction to $\mathrm{Co}^{2+}$ while the higher peak, between 349 and $360{ }^{\circ} \mathrm{C}$, is due to $\mathrm{CoO}$ reduction to metallic cobalt [2]. The reduction peak at $952{ }^{\circ} \mathrm{C}$ is due to the reduction of $\mathrm{Nb}_{2} \mathrm{O}_{5}$ phase [35] which is mainly present in the $\mathrm{CoNb}$ and $\mathrm{CoMgNb}$ samples, as seen by DRX, while the shoulders near to 778 ${ }^{\circ} \mathrm{C}$ could be attributed to the reduction of cobalt niobate phases $\left(\mathrm{CoNb}_{2} \mathrm{O}_{6}\right.$ and $\left.\mathrm{Co}_{4} \mathrm{Nb}_{2} \mathrm{O}_{9}\right)$. The cobalt oxide reduction peak at $349^{\circ} \mathrm{C}$ as well as the niobium oxide reduction zone at 778 and $952^{\circ} \mathrm{C}$ for $\mathrm{CoNb}$ sample was slightly shifted to higher temperatures for samples profiles containing modifiers. It shows that the presence of modifiers increases the cobalt oxide interaction with niobium oxide. Other authors [21] also observed this interaction. On the other hand, it was noted that Ca or Sr addition increased cobalt and niobium oxides reducibility, once a greater area under the reduction peaks was observed, according to $\mathrm{CoCaNb}$ profiles and $\mathrm{CoSrNb}$ samples. The opposite occurred with $\mathrm{CoMgNb}$ sample, which could mean that, in this case, a cobalt and magnesium niobate species which is hard to be reduced was probably formed, as seen by XRD.

Solids showed low specific area values from 2.0 to $6.0 \mathrm{~m}^{2} \mathrm{~g}^{-1}$ (Table I), which are typical of niobium oxide [27] and cobalt oxide [4] obtained at high temperatures. Commonly, alkaline earth metals do not contribute to area increase [24], although modifiers addition slightly increased the specific area and decreased cobalt niobate mean pore diameter $(\mathrm{CoNb})$. This effect was more pronounced in samples containing strontium $(\mathrm{CoSrNb})$ which, as can be seen in all characterization results, was the dopant which changed CoNbOx properties more effectively.

Modifiers also increased cobalt niobate whole acidity, as shown in Table 1, but the strontium-containing material $(\mathrm{CoSrNb})$ showed higher total acidity than the other ones. According to $\mathrm{NH}_{3}$-TPD curves (Fig. 5), only two defined desorption regions were observed in the sample profile, corresponding to moderate acidic sites (peak with maximum at $350{ }^{\circ} \mathrm{C}$ ) and strong acidic sites (peak with maximum at $680^{\circ} \mathrm{C}$ ). For the other samples, it is probable that the adsorbed ammonia quantity was so low that, due to the equipment detection limit, it was not possible to identify the desorption peaks in TPD profiles. In all cases, whole acidity values were lower than the ones obtained by other authors [32] for pure niobium oxide $\left(403 \mu \mathrm{mol} \mathrm{NH} \mathrm{N}_{3} \mathrm{~g}^{-1}\right)$. It could show that cobalt interaction decreased niobium oxide acidity. By adding the dopants, $\mathrm{Co}-\mathrm{Nb}$ interaction weakened and acidic sites concentration in cobalt niobate increased. This effect may be more pronounced for $\mathrm{CoSrNb}$ sample because its $\mathrm{Sr} / \mathrm{Nb}$ ratio is the highest one when compared to $\mathrm{M} / \mathrm{Nb}$ ratio for the other samples (Table 1). 


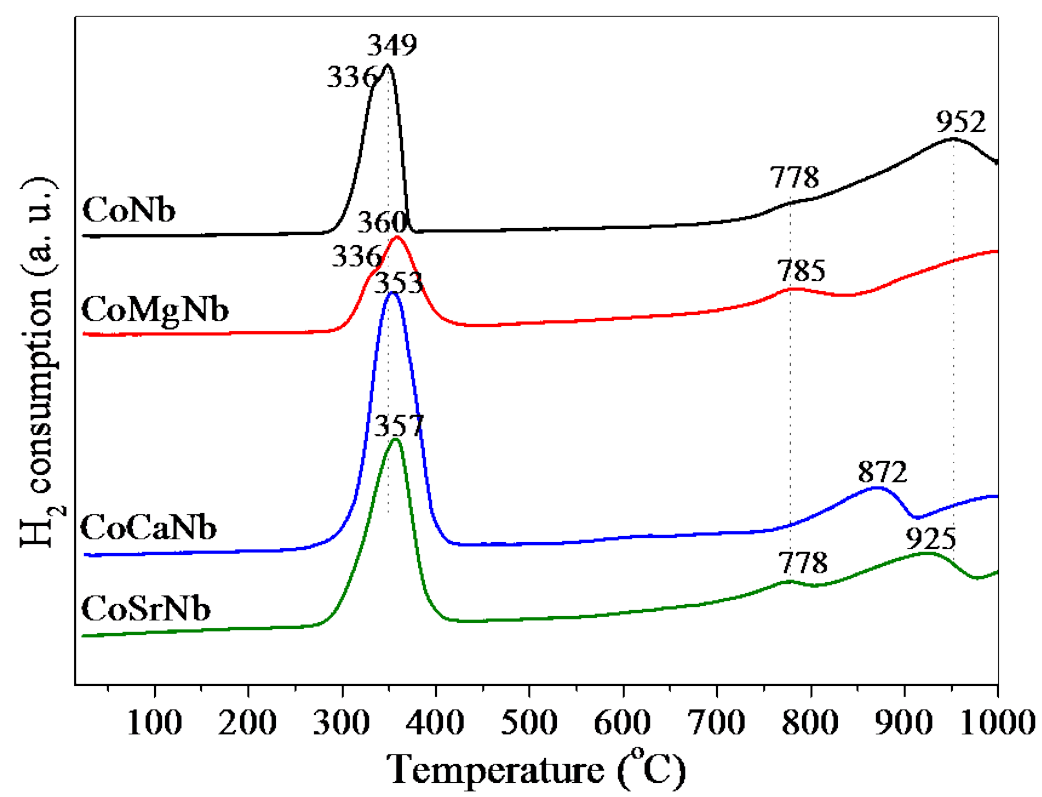

Figure 4: Oxidized samples TPR profiles.

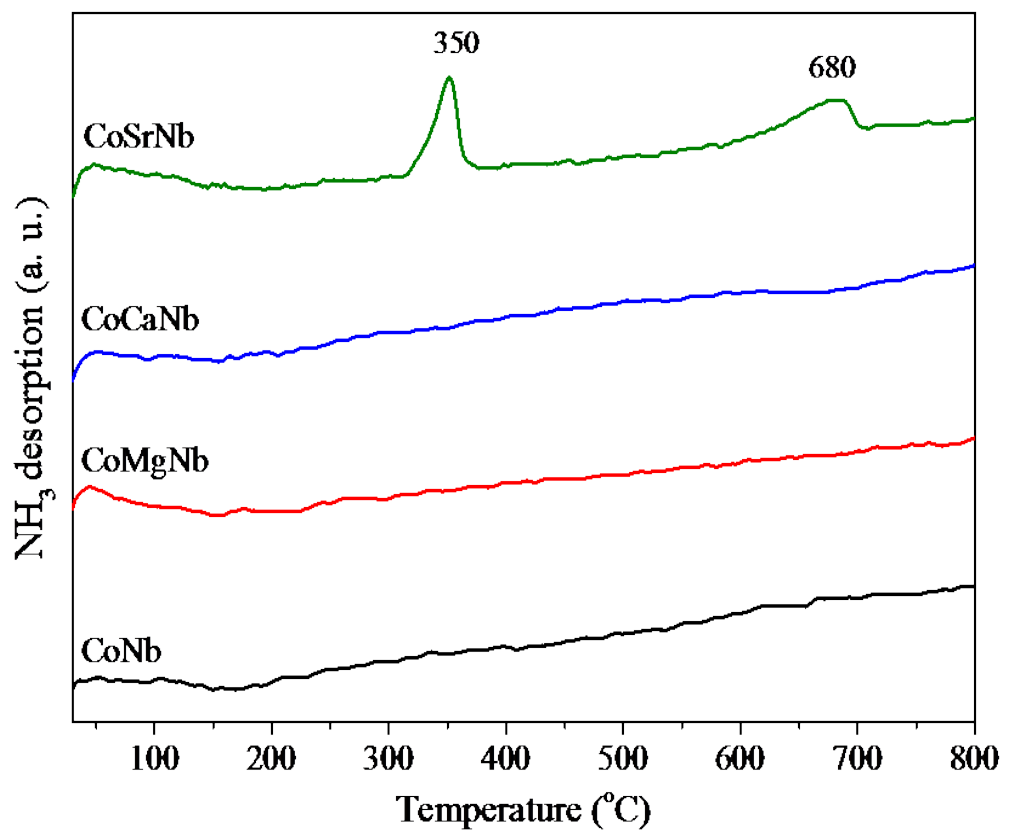

Figure 5: Cobalt niobate based samples $\mathrm{NH}_{3}-\mathrm{TPD}$ profiles.

The effect of modifiers $(\mathrm{Mg}, \mathrm{Ca}$, and $\mathrm{Sr})$ on $\mathrm{Co}-\mathrm{Nb}$ based catalysts metallic function activity was evaluated by cyclohexane dehydrogenation reaction and the results are shown in Table 2. Cyclohexane dehydrogenation is frequently used as a model reaction to evaluate metallic sites activity because it is a non-demanding reaction [36], that is, it does not require specific atomic arrangement to take place. Therefore, the conversion values are a function of the active centers number exposed on the catalyst surface. According to TPR profiles, magnesium and niobium oxides were not reduced in the reduction conditions used in this work. Therefore, they remained mainly as oxides species, without activity for dehydrogenation. Thus, the cyclohexane conversion values were due to cobalt atoms, which are active for dehydrogenation $[5,13]$. Table 2 shows that cyclohexane conversion with $\mathrm{CoNb}$ decreased when the modifier was added. It means that $\mathrm{Mg}, \mathrm{Ca}, \mathrm{or} \mathrm{Sr}$ could be electronically interacting with $\mathrm{Co}$, making it rich in electrons. Consequently, its hydrogen chemisorption capacity could have been reduced (electronic effect) or cobalt atoms could have been covered by alkaline earth metal niobates, as seen by the SEM images, and so be less available to dehydrogenate cyclohexane (geometric effect). The inhibitor effect regarding Co activity was lower with $\mathrm{Ca}$ addition, probably due to higher cobalt amount which was reduced for $\mathrm{CoCaNb}$ catalysts, as it can be seen by the TPR profile first peak underneath area. However, a higher amount of cobalt species was present on CoCaNb sample surface when compared to the other samples, as showed by EDS data. Some authors attribute 
the cobalt metallic activity decrease to SMSI effect [31,32]. Niobium oxide partial reduction, confirmed by TPR results, can contribute to cover the cobalt particle metal surface. On the other hand, the conversion values were similar to the samples containing $\mathrm{Mg}$ or $\mathrm{Sr}(\mathrm{CoMgNb}$ and $\mathrm{CoSrNb}$, respectively). In this case, using $\mathrm{Mg}$ or $\mathrm{Sr}$ as dopants in cobalt niobate based catalysts can be advantageous, because they decrease the highly hydrogenated coke precursors production during carbon compounds reforming.

Table 2: Cyclohexane conversion values $\left(\mathrm{X}_{\mathrm{CH}} \%\right)$ with the cobalt niobate based samples.

\begin{tabular}{cc}
\hline CATALYST & $\mathbf{X}_{\mathrm{CH}} \%$ \\
\hline $\mathrm{CoNb}$ & 1.80 \\
$\mathrm{CoMgNb}$ & 0.72 \\
$\mathrm{CoCaNb}$ & 1.15 \\
$\mathrm{CoSrNb}$ & 0.73 \\
\hline
\end{tabular}

\section{CONCLUSIONS}

In this work, cobalt and niobium oxide solids modified with alkaline earth metals $(\mathrm{Mg}, \mathrm{Ca}$, and $\mathrm{Sr}$ ) were synthesized by co-precipitation, characterized and evaluated for cyclohexane dehydrogenation reaction. The results showed that the second element addition: (i) changed cobalt niobate crystalline structure, producing alkaline earth metal niobates with lower crystallinity as well as segregated cobalt oxides; (ii) slightly increased cobalt niobate specific area; (iii) contrary to expectations, increased cobalt niobate acidity, and this effect was more pronounced for solids containing strontium; (iv) modified cobalt niobate reduction behavior so that the amount of reduced cobalt species was higher with Ca-containing material and lower with Mg-containing solid, probably due to a stable magnesium and cobalt niobate phase formation, hard to be reduced.

The solids showed slight activity for cyclohexane dehydrogenation, which decreased with the presence of donates. However, the solid with calcium showed the best result. These effects were more pronounced with $\mathrm{Mg}$ or $\mathrm{Sr}$ addition. It indicates that their use in cobalt niobate based catalysts could be suitable to decrease cobalt dehydrogenation activity, it may generate less highly dehydrogenated coke precursors on the catalyst surface during carbon compounds reforming. However, one must be careful with the Sr effect on increasing cobalt niobate acidity, as this may favor cracking reactions, which contributes to coke formation.

\section{ACKNOWLEDGEMENTS}

The authors thank PRPGI and FAPESB for financial support, CBMM for niobium oxide donation, Carina Soares for XRD and SEM analyses and Sarah Borges for Raman spectroscopy analysis.

\section{BIBLIOGRAPHY}

[1] MARTINS, A. R., et al. "Hydrogen production on alumina-supported platinum catalysts". Journal of Molecular Catalysis A: Chemical, v. 429, pp. 1-9, 2017.

[2] SREEVARDHAN REDDY, S., et al. "Novel and efficient cobalt encapsulated SBA-15 catalysts for the selective oxidation of cyclohexane”. Catalysis Today, v. 141, n. 1-2, pp. 61-65, 2009.

[3] OLIVEIRA, H. A., FRANCESCHINIB, D. F., PASSOS, F. B. "Cobalt Catalyst Characterization for Methane Decomposition and Carbon Nanotube Growth”. Journal of the Brazilian Chemical Society, v. 25, n. 12, pp. 2339-2349, 2014.

[4] TRIGUEIRO, F., et al. "Effect of niobium addition to $\mathrm{Co} / \gamma-\mathrm{Al} 2 \mathrm{O} 3$ catalyst on methane combustion". Catalysis Today, v. 118, n. 3-4, pp. 425-432, 152006.

[5] SILVA, R. R. C. M., et al. "Reações de desidrogenação e hidrogenólise do cicloexano em catalisadores de cobalto suportados em nióbia e alumina (cyclohexane dehydrogenation and hydrogenolysis reactions in cobalt catalysts supported on niobia and alumina) ". Engevista, v. 17, n. 2, pp. 207, 312014.

[6] TAVASOLI, A., et al. "Fischer-Tropsch synthesis over cobalt catalyst supported on carbon nanotubes in a slurry reactor". Applied Catalysis A: General, v. 345, n. 2, pp. 134-142, 2008.

[7] LLORCA, J. "Efficient Production of Hydrogen over Supported Cobalt Catalysts from Ethanol Steam Reforming". Journal of Catalysis, v. 209, n. 2, pp. 306-317, 2002. 
[8] BATISTA, M. S., et al. "High efficiency steam reforming of ethanol by cobalt-based catalysts. Journal of Power Sources, v. 134, n. 1, pp. 27-32, jul. 2004.

[9] SOUSA, F. F., et al. "Nanostructured Ni-containing spinel oxides for the dry reforming of methane : Effect of the presence of cobalt and nickel on the deactivation behaviour of catalysts. International Journal of Hydrogen Energy, v. 37, n. 4, pp. 3201-3212, 2011.

[10] SILVA, M. A., et al. "Desenvolvimento de protótipo de células a combustível do tipo óxido sólido com reforma direta". Matéria (Rio de Janeiro), v. 12, n. 1, pp. 99-110, 2007.

[11] PADILLA, R., et al. "Nickel and cobalt as active phase on supported zirconia catalysts for bio-ethanol reforming: Influence of the reaction mechanism on catalysts performance". International Journal of Hydrogen Energy, pp. 2-9, 2010.

[12] OLIVEIRA, J. S., et al. "Síntese de CoFe2O4 sobre os suportes MgAl2O4 e ZSM-5 para uso na degradação de poluente orgânico pelo processo foto-Fenton heterogêneo sob irradiação visível e solar". Matéria (Rio de Janeiro), v. 24, n. 4, 2019.

[13] LEE, S., et al. Oxidative dehydrogenation of cyclohexene on size selected subnanometer cobalt clusters: improved catalytic performance via evolution of cluster-assembled nanostructures". Physical Chemistry Chemical Physics, v. 14, n. 26, pp. 9336, 2012.

[14] GUO, Y., et al. "Carbon dioxide reforming of methane over cobalt catalysts supported on hydrotalcite and metal oxides”. Catalysis Communications, v. 116, pp. 81-84, 2018.

[15] WANG, H. Y.; RUCKENSTEIN, E. "Conversions of methane to synthesis gas over Co/ $\gamma$-A12O3 by CO2 and/or O2". Catalysis Letters, v. 75, n. 1-2, pp. 13-18, 2001.

[16] EL HASSAN, N., et al. "Low temperature dry reforming of methane on rhodium and cobalt based catalysts: Active phase stabilization by confinement in mesoporous SBA-15”. Applied Catalysis A: General, v. 520, pp. 114-121, 2016.

[17] NICO, C.; MONTEIRO, T.; GRAÇA, M. P. F. "Niobium oxides and niobates physical properties: Review and prospects". Progress in Materials Science, v. 80, pp. 1-37, 2016.

[18] SOUSA, R. M. F. ; FERNANDES, L. E., GUERRA, W. “Nióbio”. Química Nova na Escola, v. 35, pp. 68-69, 2013.

[19] ALVES, A. R., COUTINHO, A. R. "The Evolution of the Niobium Production in Brazil”. Materials Research, v. 18, n. 1, pp. 106-112, 2015.

[20] CARVALHO, L. S., et al. "Preparation and characterization of $\mathrm{Ru} / \mathrm{MgO}-\mathrm{Al} 2 \mathrm{O} 3$ catalysts for methane steam reforming”. Catalysis Today, v. 142, n. 1-2, pp. 52-60, 2009.

[21] VIZCAÍNO, A. J., CARRERO, A., CALLES, J. A. "Comparison of ethanol steam reforming using Co and Ni catalysts supported on SBA-15 modified by Ca and Mg”. Fuel Processing Technology, v. 146, pp. 99-109, 2016.

[22] GERVASINI, A., et al. "Effect of the $\mathrm{K}+, \mathrm{Ba} 2+$, and $\mathrm{Nd} 3+$ addition to $\mathrm{Nb} 2 \mathrm{O} 5$ on intrinsic and effective acidity in relation to biomass reactions. Journal of Catalysis", v. 296, pp. 143-155, 2012.

[23] ALIPOUR, Z., REZAEI, M., MESHKANI, F. "Effect of alkaline earth promoters ( $\mathrm{MgO}, \mathrm{CaO}$, and $\mathrm{BaO})$ on the activity and coke formation of Ni catalysts supported on nanocrystalline Al2O3 in dry reforming of methane". Journal of Industrial and Engineering Chemistry", v. 20, n. 5, pp. 2858-2863, set. 2014.

[24] MOURA, J. S., SOUZA, M. O. G., RANGEL, M. C. "Efeito da adição de magnésio nas propriedades texturais de catalisadores à base de níquel e óxido de lantânio". Matéria (Rio de Janeiro), v. 12, n. 1, pp. 29-38, 2007.

[25] SUTTHIUMPORN, K., KAWI, S. "Promotional effect of alkaline earth over NieLa2O3 catalyst for CO2 reforming of $\mathrm{CH} 4$ : Role of surface oxygen species on $\mathrm{H} 2$ production and carbon suppression”. International Journal of Hydrogen Energy, v. 36, n. 22, pp. 14435-14446, 2011.

[26] PASRICHA, R., RAVI, V. "Preparation of nanocrystalline MgNb2O6 by citrate gel method". Materials Letters, v. 59, n. 17, pp. 2146-2148, 2005.

[27] PULLAR, R. C. "The Synthesis, Properties, and Applications of Columbite Niobates (M2+Nb2O6): A Critical Review”. Journal of the American Ceramic Society, v. 92, n. 3, pp. 563-577, 2009.

[28] SIQUEIRA, K. P. F., MOREIRA, R. L., DIAS, A. "Synthesis and Crystal Structure of Lanthanide Orthoniobates Studied by Vibrational Spectroscopy”. Chemistry of Materials, v. 22, n. 8, pp. 2668-2674, 27 abr. 2010.

[29] MA, R., et al. "Hydrothermal synthesis and phase stability of CoNb2O6with a rutile structure". Materials Letters, v. 65, n. 19-20, pp. 2880-2882, 2011. 
[30] SRISOMBAT, L., ANANTA, S., PHANICHPHANT, S. "Chemical synthesis of magnesium niobate powders". Materials Letters, v. 58, n. 6, pp. 853-858, 2004.

[31] NORONHA, F. B., et al. "The promoting effect of noble metal addition on niobia-supported cobalt catalysts". Catalysis Today, v. 28, n. 1-2, pp. 147-157, 1996.

[32] BENITEZ, V. M., et al. "Influence of the metallic content on Pt-Ir/Nb2O5 catalysts for decalin selective ring opening". Catalysis Today, v. 289, pp. 53-61, 2017.

[33] WACHS, I. E. "Raman and IR studies of surface metal oxide species on oxide supports: Supported metal oxide catalysts”. Catalysis Today, v. 27, n. 3-4, pp. 437-455, 1996.

[34] HORVÁTH, É., et al. "Dry reforming of CH4 on Co/A12O3 catalysts rewduced at different temperatures". Catalysis Today, v. 281, pp. 233-240, 2017.

[35] ALONSO, C. G., et al. "Reactions over $\mathrm{Cu} / \mathrm{Nb} 2 \mathrm{O} 5$ catalysts promoted with $\mathrm{Pd}$ and $\mathrm{Ru}$ during hydrogen production from ethanol”. International Journal of Hydrogen Energy, v. 34, n. 8, pp. 3333-3341, 2009.

[36] SILVA, L. A., et al. "Evaluation of nickel and copper catalysts in biogas reforming for hydrogen production in SOFC". Matéria (Rio de Janeiro), v. 22, n. 1, 2017.

\section{ORCID}

Maiana Pinheiro Sena Simone Pereira de Lima Luciene Santos Carvalho Doris Ruiz

Adriana Ballarini

André Rosa Martins https://orcid.org/0000-0001-5332-3338

https://orcid.org/ 0000-0002-3566-5358

https://orcid.org/0000-0002-1218-4236

http://orcid.org/0000-0002-1389-8927

https://orcid.org/0000-0002-5383-8777

https://orcid.org/0000-0001-8933-8080 